\title{
Overexpression of Bcl-2 Reduces Sex Differences in Neuron Number in the Brain and Spinal Cord
}

\author{
Susan L. Zup, ${ }^{1}$ Heather Carrier, ${ }^{1}$ Elizabeth M. Waters, ${ }^{2}$ Abigail Tabor, ${ }^{1}$ Lynn Bengston, ${ }^{1}$ Greta J. Rosen, ${ }^{1}$ \\ Richard B. Simerly, ${ }^{2}$ and Nancy G. Forger ${ }^{1}$ \\ ${ }^{1}$ Department of Psychology and Center for Neuroendocrine Studies, University of Massachusetts, Amherst, Massachusetts 01003, and ${ }^{2}$ Oregon Regional \\ Primate Research Center, Division of Neuroscience, Beaverton, Oregon 97006
}

\begin{abstract}
Several sex differences in the nervous system depend on differential cell death during development in males and females. The antiapoptotic protein, Bcl-2, promotes the survival of many types of neurons during development and in response to injury. To determine whether Bcl-2 might similarly control cell death in sexually dimorphic regions, we compared neuron number in wild-type mice and transgenic mice overexpressing Bcl-2 under the control of a neuron-specific promoter. Three neural areas were examined: the spinal nucleus of the bulbocavernosus (SNB), in which neuron number is greater in males; the retrodorsolateral nucleus (RDLN) of the spinal cord, which exhibits no sex difference in neuron number; and the anteroventral periventricular nucleus (AVPV) of the hypothalamus, in which both overall cell density and the number of tyrosine hydroxylase immunoreactive (TH-ir) neurons are greater in females. Bcl-2 overexpression significantly increased SNB cell number in females, overall cell density of AVPV in males, and RDLN cell number in both sexes. Bcl-2 overexpression did not alter the number of TH-ir neurons in AVPV of males or females. These findings indicate that Bcl-2 can regulate sexually dimorphic cell number in the brain and spinal cord and suggest that Bcl-2 may mediate effects of testosterone on cell survival during neural development. In contrast to the regulation of overall cell density in AVPV, the sex difference in TH cell number apparently is not caused by a Bcl-2-dependent mechanism.
\end{abstract}

Key words: Bcl-2; sex difference; cell death; nervous system; spinal nucleus of the bulbocavernosus; anteroventral periventricular nucleus

\section{Introduction}

Sex differences in neuron number have been described in the mammalian nervous system and often can be attributed to the hormonal control of cell death (Tobet and Hanna, 1997; Forger, 2001). Testosterone, produced by the testes during perinatal life, increases cell death in some neural regions, whereas it decreases death in others. In the spinal nucleus of the bulbocavernosus (SNB), a cluster of motoneurons in the lumbar cord which innervates penile muscles, testosterone acts via androgen receptors to prevent cell death (Breedlove and Arnold, 1983; Nordeen et al., 1985). As a result, adult males have many more SNB cells than do females (Breedlove and Arnold, 1980). Conversely, the anteroventral periventricular nucleus (AVPV), a nucleus at the rostral extreme of the third ventricle implicated in the control of gonadotrophin release, is larger and exhibits greater cell density in females than in males (Bleier et al., 1982; Sumida et al., 1993). These sex differences are attributable, at least in part, to the fact that testosterone or its estrogenic metabolites increase cell death in AVPV during perinatal life (Murakami and Arai, 1989; Nishizuka et al., 1993; Sumida et al., 1993; Arai et al., 1996). Females also have many more dopaminergic neurons in AVPV than do males (Simerly, 1998), but it is not known whether this sex dif-

Received Aug. 27, 2002; revised Dec. 30, 2002; accepted Dec. 31, 2002.

This work was supported by National Institutes of Health Grants HD33044 (N.G.F.), HD01188 (N.G.F.), and NS37952 (R.B.S.). We are grateful for the excellent technical assistance provided by Jennifer Pfau and Sabrine Montaldo.

Correspondence should be addressed to Nancy G. Forger, Department of Psychology, University of Massachusetts, Amherst, MA 01003. E-mail: nforger@psych.umass.edu.

Copyright $\odot 2003$ Society for Neuroscience $\quad 0270-6474 / 03 / 232357-06 \$ 15.00 / 0$ ference arises as the result of differential cell death in males and females or some other mechanism. Although the development of sex differences in neuron number has been best studied in rats, the sex differences in the SNB and AVPV and their developmental dependence on gonadal steroid hormones are similar in mice (Wee and Clemens, 1987; Wagner and Clemens, 1989; Forger et al., 1997; Simerly et al., 1997).

In many neural regions, developmental cell death is critically controlled by the Bcl-2 family of proteins. Some family members, such as Bcl-2 itself, promote cell survival, whereas other family members promote cell death. According to the "rheostat" model of cell death, it is the ratio of pro-life to pro-death molecules that determines whether a cell will live or die (Yang and Korsmeyer, 1996), and elevated expression of a survival-promoting family member should reduce the likelihood of cell death. Indeed, overexpression of Bcl-2 has been shown to prevent neuronal cell death in several experimental paradigms (Allsopp et al., 1993; Dubois-Dauphin et al., 1994; Martinou et al., 1994; Bonfanti et al., 1996). The effect of Bcl-2 overexpression on developmental cell death in sexually dimorphic regions, however, has not been explored.

In the present study, the SNB and AVPV were examined in transgenic mice overexpressing $\mathrm{Bcl}-2$ under the control of a neuron-specific promoter. We reasoned that if Bcl-2 normally promotes cell survival in these regions, then $\mathrm{Bcl}-2$ overexpression might prevent cell death, thereby reducing or eliminating sex differences that depend on differential apoptosis in males and females. For comparison, we also examined the retrodorsolateral nucleus (RDLN), a spinal nucleus in which cell number is neither sexually dimorphic nor affected by perinatal hormone treatments (Jordan et al., 1982; Leslie et al., 1991). 


\section{Materials and Methods}

Animals. Transgenic male mice overexpressing human Bcl-2 under the control of the neuron-specific enolase promoter [line NSE73a in Martinou et al. (1994)] were obtained from Dr. J. C. Martinou (University of Geneva, Geneva, Switzerland) through Dr. Flint Beale (Massachusetts General Hospital, Boston, MA). This line was chosen because expression of the transgene is targeted to the nervous system and can be detected in essentially all postmitotic neurons of the brain and spinal cord by embryonic day 13. Moreover, expression of the transgene far exceeds the production of endogenous mouse Bcl-2, i.e., there is true "overexpression" of Bcl-2 in these animals (Martinou et al., 1994). We used antibodies specific for human $\mathrm{Bcl}-2$ to verify that the transgene is abundantly expressed in the SNB, RDLN, and AVPV of the overexpressors (Park et al., 2002; E. M. Waters and R. B. Simerly, unpublished observations).

Wild-type and $\mathrm{Bcl}-2$ overexpressing offspring were generated by mating Bcl-2 overexpressing males with B6D2F1 females (The Jackson Laboratory, Bar Harbor ME) and were genotyped by PCR amplification of tail DNA using published primer sequences (Coulpier et al., 1996). Mice were housed in groups of three to four in a $12 \mathrm{hr}$ light/dark cycle and held at $24^{\circ} \mathrm{C}$. Adult mice $(60-90 \mathrm{~d}$ old $)$ were overdosed with pentobarbital and then perfused intracardially with saline followed by $4 \%$ paraformaldehyde.

Motoneuron size and number. Motoneurons in the SNB and RDLN were examined in 36 mice ( $n=7-10$ animals per group). Lumbosacral spinal cords were dissected out, postfixed in $10 \%$ formalin, and immersed in Bouin's solution for $48 \mathrm{hr}$ before paraffin embedding. Serial, $12 \mu \mathrm{m}$ coronal sections were collected, mounted on slides, and thionin stained. Mean cell size for both SNB and RDLN motoneurons was determined by camera lucida tracings of the somas and nuclei of at least 20 motoneurons per nucleus, per animal. Sections chosen for tracing were spaced equally throughout the rostrocaudal extent of each cell group, and all possible motoneurons from these sections were traced to avoid experimenter bias.

SNB and RDLN motoneurons were counted in alternate sections as in previous studies (Forger et al., 1997; Park et al., 1999). Only motoneurons with a clearly visible nucleus and nucleolus were included in the analysis; the SNB was counted bilaterally, and motoneurons in the RDLN were counted unilaterally. The Konigsmark correction (Konigsmark, 1970) was then used to correct raw motoneuron counts for sampling ratio and for overcounting of split cells on the basis of the size of the object counted (motoneuronal nucleus) in each animal. In preliminary counts, the RDLN population appeared heterogeneous, containing a subpopulation of cells that were small but nonetheless exhibited the classic staining characteristics of motoneurons. Therefore, counts of RDLN motoneurons were divided into "small" or "average" cells on the basis of simple visual inspection by an experimenter blind to treatment groups.

AVPV overall cell density and tyrosine hydroxylase cell number. Brains were removed from the skulls of 29 mice ( $n=5-9$ per group), blocked, placed in $15 \%$ sucrose overnight, and then sectioned at $30 \mu \mathrm{m}$ in the coronal plane on a freezing microtome. Serial sections were mounted on slides and thionin stained. Cell density counts were made on two sections in AVPV of each animal, at a final magnification of $1000 \times$. For counting, an eye-piece reticule was used to superimpose a grid $(192 \times 240 \mu \mathrm{m})$ on AVPV. The grid was lined up against the third ventricle, and only darkly staining cells with the characteristic morphology of neurons were counted by an observer blind to treatment groups. The mean of the counts was determined and designated as "total cell density" for that animal. This method of counting is similar to that used previously to estimate neuron density in AVPV (Sumida et al., 1993). Cell size was determined by tracing the soma and nucleus of at least 50 neurons in two sections through AVPV, and tracings were imported into SigmaScan to determine cross-sectional areas. Because there was no effect of sex or genotype on cell size in AVPV (see below), no corrections were made for double-counting of split cells. Thus, the cell densities reported may slightly overestimate the density of neurons present in AVPV, but between-group comparisons should remain valid. Nucleus length was determined by multiplying the number of sections containing the AVPV by the section thickness.
A small subset of all neurons in AVPV are dopaminergic, as identified by tyrosine hydroxylase (TH) immunoreactivity, and females have many more TH-immunoreactive (TH-ir) neurons in AVPV than do males (Simerly et al., 1985, 1997). To determine whether Bcl-2 influences the number of dopaminergic neurons in AVPV, brains were harvested from a separate cohort of mice ( $n=4-6$ per group) perfused with $4 \%$ paraformaldehyde in borate buffer, $\mathrm{pH}$ 9.5. Coronal sections $(20 \mu \mathrm{m})$ through AVPV were immunostained for TH and estrogen receptor $\alpha$, as described previously (Simerly et al., 1997), using mouse anti-tyrosine hydroxylase antiserum (1:1000; DiaSorin, Stillwater, MN) and rabbit anti-estrogen receptor $\alpha$ (1:40,000; Upstate, Waltham, MA). The primary antibodies were localized with goat anti-mouse secondary conjugated to Alexa 488 and goat anti-rabbit secondary conjugated to Alexa 586 (Molecular Probes, Eugene, OR). Estrogen receptor $\alpha$-immunoreactive cells were used to select sections containing AVPV and to identify the borders of the AVPV from each animal. TH-ir cells with clearly visible nuclei were counted in all sections containing the AVPV.

Data analysis. The effects of sex and Bcl-2 overexpression on SNB and RDLN motoneuron number and size as well as AVPV length, cell density, cell size, and TH-ir cell number were evaluated using separate two-way ANOVAs. Planned comparisons were performed after significant main effects using Fisher's LSD.

\section{Results}

\section{Effects of Bcl-2 overexpression on SNB motoneurons}

The robust sex difference in SNB cell number seen previously in rats and mice was confirmed, with males having many more motoneurons than females $\left(F_{(1,32)}=73.0 ; p<0.0005\right)$ (Fig. 1). There was no main effect of Bcl-2 overexpression on SNB cell number $\left(F_{(1,32)}=3.0 ; p=0.09\right)$. However, there was a significant sex-by-genotype interaction $\left(F_{(1,32)}=6.7 ; p<0.05\right)$, attributable to the fact that $\mathrm{Bcl}-2$ overexpression increased $\mathrm{SNB}$ motoneuron number by $53 \%$ in females $(p<0.005)$ and did not affect cell number in males $(p>0.56)$ (Fig. 1). In accord with previous observations, males had larger SNB motoneuron somas and nuclei than did females $(p<0.0005$ in both cases) (Table 1$)$. There was no effect of Bcl-2 overexpression and no sex-by-genotype interaction on SNB cell size.

\section{Effects of Bcl-2 overexpression on the RDLN}

$\mathrm{Bcl}-2$ overexpression significantly increased the total number of RDLN motoneurons, with overexpressing mice having $\sim 22 \%$ more RDLN motoneurons than their wild-type siblings $\left(F_{(1,32)}=\right.$ $27.0 ; p<0.0005)$ (Fig. $2 A$ ). There was no main effect of sex and no sex-by-genotype interaction on total number of RDLN cells, and planned comparisons confirm that the increase was significant within both males and females ( $p<0.005$ in both cases). A population of small motoneurons was noted within the RDLN that, across groups, accounted for $\sim 15 \%$ of the total. Bcl- 2 overexpression significantly increased the number of both "small" and "average" RDLN cells, but the effect was much more pronounced on the small cells: Bcl-2 overexpressors had 114\% more small $(p<0.0005)$ (Fig. $2 B)$ and 9\% more average RDLN cells than did wild-type mice ( $p<0.05$; data not shown). As a result, mean RDLN motoneuron nucleus and soma sizes were decreased in Bcl-2-overexpressing mice $(p<0.01)$ (Table 1$)$. There was no main effect of sex and no sex-by-genotype interaction on RDLN cell size. Thus, Bcl-2 overexpression increased motoneuron number in the RDLN of both males and females, and many of the supernumerary cells were small.

\section{Effect of Bcl-2 overexpression on AVPV cell density, nucleus length, and $\mathrm{TH}$-ir cell number}

As reported previously (Bleier et al., 1982; Sumida et al., 1993), there was a modest sex difference in AVPV cell density, with 


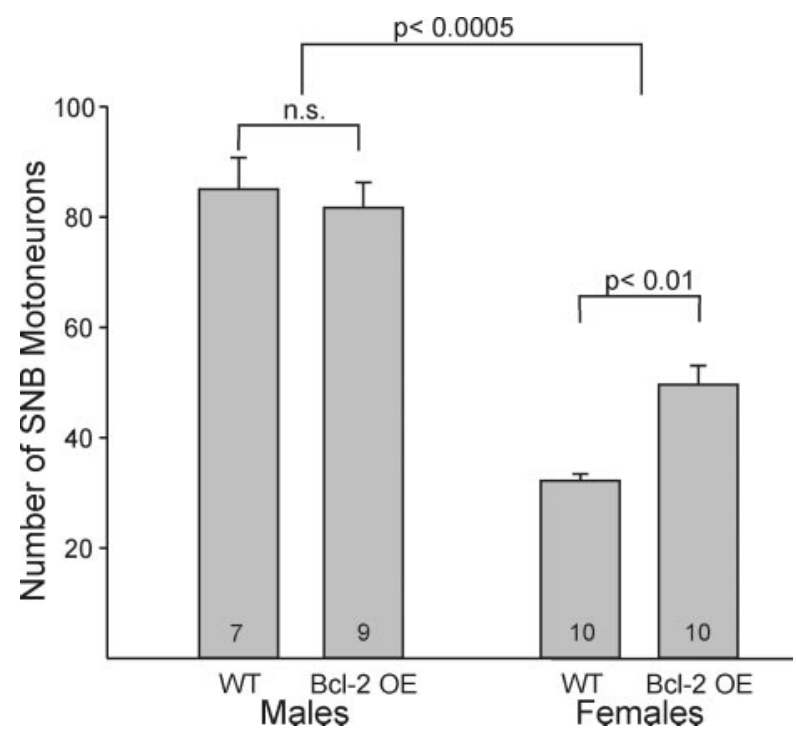

Figure 1. The mean ( $\pm S E M)$ number of SNB motoneurons in wild-type $(W T)$ and $\mathrm{BCl}-2$ overexpressing $(\mathrm{BCl}-2 \mathrm{OE})$ mice. $\mathrm{BCl}$-2 overexpression increased motoneuron number in females but not in males. $n=$ numbers at base of bars. n.s., Not significant.

higher densities in females $\left(F_{(1,25)}=8.1 ; p<0.01\right)$ (Fig. 3A). Bcl-2 overexpression increased overall cell density in AVPV $\left(F_{(1,25)}=11.2 ; p<0.005\right)$, and planned comparisons indicate that this increase was significant for males $(p<0.005)$ but not for females $(p>0.1)$. As a result, the sex difference in cell density was no longer significant in $\mathrm{Bcl}$-2-overexpressing mice. There was no effect of either sex or Bcl-2 expression on nucleus or soma size in AVPV (Table 1). AVPV volume has also been reported to be greater in female mice than in males, and this sex difference is attributable primarily to the fact that the nucleus is longer in females (Bleier et al., 1982). In the current sample, nucleus length tended to be greater in females than in males, but this difference did not reach statistical significance $\left(F_{(1,25)}=3.6 ; p=0.069\right)$. There was no effect of Bcl-2 overexpression on length of AVPV.

In confirmation of previous reports (Simerly et al., 1985, 1997), the number of TH-ir cells in the present study was 3.3 times greater in females than in males $(p<0.0005)$. However, there was no effect of Bcl-2 overexpression and no sex-bygenotype interaction on TH cell number. Thus, Bcl-2 overexpression increased overall cell density in AVPV of male mice but did not influence the number of TH-positive cells.

\section{Discussion}

$\mathrm{Bcl}-2$ rescues many types of neurons from apoptosis caused by injury or disease and can enhance neuronal survival during development (Allsopp et al., 1993; Martinou et al., 1994; Farlie et al., 1995; Bonfanti et al., 1996). Here we examined whether Bcl-2 might also be involved in sexually dimorphic cell death in the CNS. In accord with previous reports, male wild-type mice had many more SNB motoneurons than did females, and, conversely, females had a higher overall cell density in the AVPV than did males. Bcl-2 overexpression significantly increased the number of SNB motoneurons in females and AVPV

n.s., Not significant. neuronal density in male mice. In the RDLN, which exhibits no sex difference in neuron number, Bcl-2 overexpression increased motoneuron number similarly in both sexes. Thus, in addition to its well established role in controlling neuronal number in nondimorphic neural regions, $\mathrm{Bcl}-2$ may control cell number in sexually dimorphic cell groups.

The most likely explanation for the increased number of neurons seen in the overexpressors is that $\mathrm{Bcl}-2$ saved neurons from developmental cell death. The forced overexpression of Bcl-2 prevents the death of developing neurons in vitro and in vivo (Allsopp et al., 1993; Martinou et al., 1994; Farlie et al., 1995). Moreover, the neuron-specific enolase promoter, which controlled expression of $\mathrm{Bcl}-2$ in the mice used here, is not produced at high levels until neurons become functionally and morphologically mature (Marangos et al., 1980), making it unlikely that Bcl-2 altered neuron number by affecting neurogenesis. Thus, although we cannot definitively rule out other explanations, these considerations support the interpretation that Bcl-2 overexpression increased neuron number by maintaining neurons that would otherwise die in the developing SNB, AVPV, and RDLN.

Although Bcl-2 overexpression significantly increased motoneuron number in the SNB of females, the sparing was not complete: female overexpressors still had significantly fewer SNB cells than did males. The Bcl-2 transgene in the line of mice used here is reported to be expressed in all postmitotic neurons of the spinal cord by embryonic day 13 (Martinou et al., 1994), i.e., well before the perinatal cell death period in the SNB. However, because the level of expression of Bcl-2 specifically within SNB motoneurons during the perinatal period is not known, it remains possible that Bcl-2 protein levels in the SNB were not high enough or produced early enough during the cell death period to rescue all SNB cells of females. It is also possible that Bcl-2 overexpression transiently saved some SNB motoneurons that subsequently died because of lack of trophic support. Target-derived trophic factors are important regulators of motoneuronal cell death during development (Hollyday and Hamburger, 1976; Oppenheim, 1991). SNB motoneurons project to the striated perineal muscles bulbocavernosus (BC), levator ani (LA), and external anal sphincter (Schroder, 1980). Although the BC and LA initially form in both sexes, these muscles remain vestigial (LA) or degenerate (BC) in females during perinatal life, and it is the loss of target muscles that is thought to account for the massive death of SNB motoneurons in females (Cihak et al., 1970; Tobin and Joubert, 1991; Forger et al., 1992). The BC/LA muscles could not be identified by gross dissection of adult females in the present study, regardless of genotype, suggesting that Bcl-2 overexpression does not "masculinize" SNB target muscles. Similarly, reconstructions of BC/LA muscle volumes in newborn females in-

Table 1. Neuronal cell size $\left(\mu \mathrm{m}^{2}\right)$ in wild-type and Bcl-2-overexpressing mice

\begin{tabular}{|c|c|c|c|c|c|c|}
\hline & \multicolumn{2}{|l|}{ SNB } & \multicolumn{2}{|l|}{ RDLN } & \multicolumn{2}{|l|}{ AVPV } \\
\hline & Soma & Nucleus & Soma & Nucleus & Soma & Nucleus \\
\hline \multicolumn{7}{|l|}{ Males } \\
\hline Wild type & $346 \pm 22$ & $120 \pm 8$ & $302 \pm 21$ & $121 \pm 7$ & $50 \pm 2$ & $33 \pm 1$ \\
\hline $\mathrm{Bcl}-20 \mathrm{E}$ & $358 \pm 13$ & $121 \pm 4$ & $278 \pm 13$ & $101 \pm 5$ & $47 \pm 1$ & $34 \pm 1$ \\
\hline \multicolumn{7}{|l|}{ Females } \\
\hline Wild type & $226 \pm 11$ & $84 \pm 4$ & $301 \pm 12$ & $117 \pm 5$ & $48 \pm 3$ & $33 \pm 1$ \\
\hline $\mathrm{BCl}-2 \mathrm{OE}$ & $235 \pm 10$ & $84 \pm 3$ & $255 \pm 6$ & $98 \pm 4$ & $47 \pm 2$ & $32 \pm 1$ \\
\hline \multicolumn{7}{|l|}{ ANOVA: } \\
\hline Sex & $p<0.0005$ & $p<0.0005$ & n.s. & n.s. & n.s. & n.s. \\
\hline Genotype & n.s. & n.s. & $p<0.01$ & $p<0.001$ & n.s. & n.s. \\
\hline Interaction & n.s. & n.s. & n.s. & n.s. & n.s. & n.s. \\
\hline
\end{tabular}



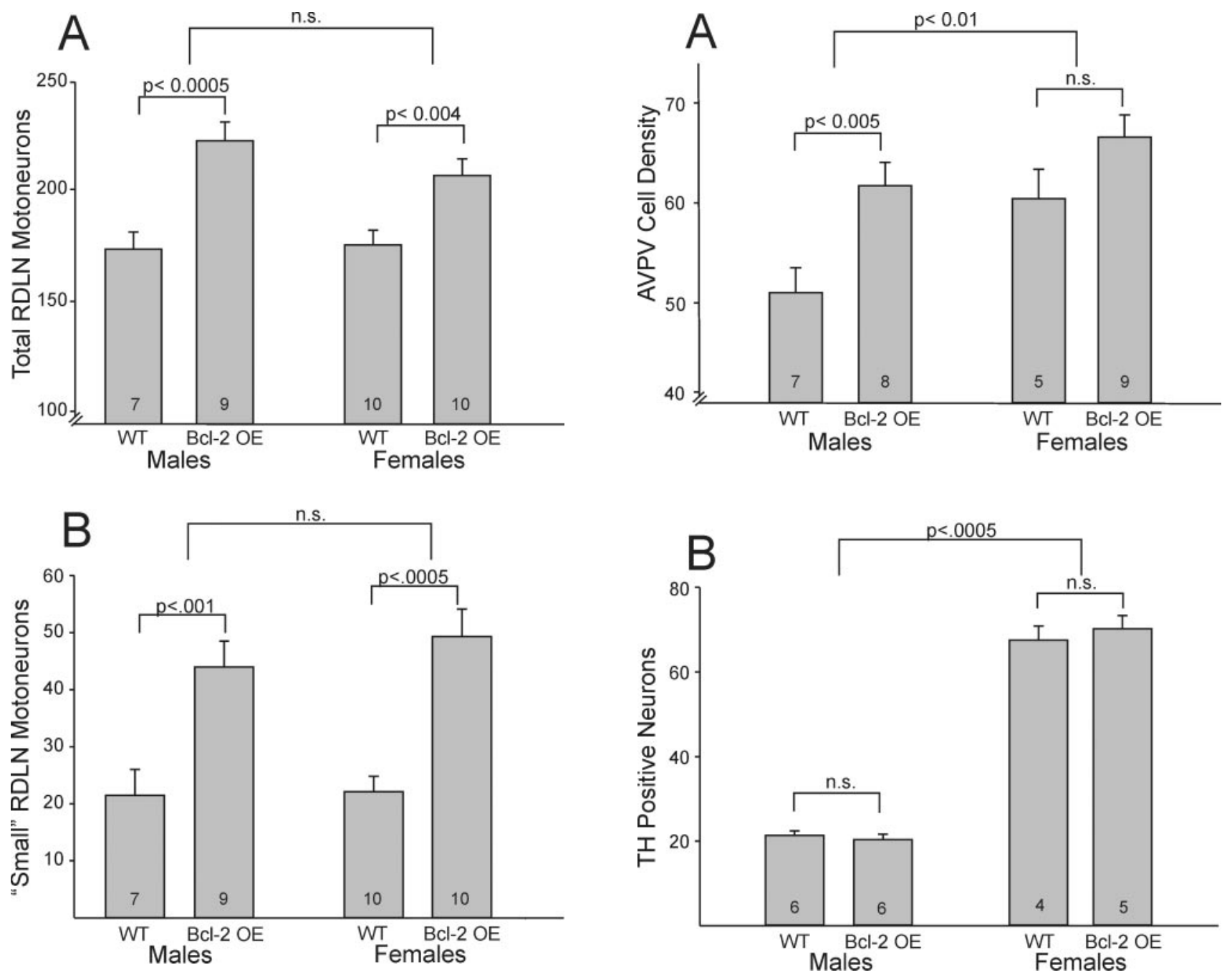

Figure 2. Motoneuron number in the RDLN of wild-type and BCl-2-overexpressing mice. $A$, There was no sex difference in RDLN cell number. BCl-2 overexpression increased the total number of RDLN motoneurons by $\sim 22 \%$, and the increase was significant for both sexes. $B$, The number of RDLN motoneurons classified as small was increased by $114 \%$ in $\mathrm{BCl}-2$ overexpressing mice; this increase was significant for both males and females. $n=$ numbers at base of bars.

dicate no effect of Bcl-2 transgene expression on muscle size during the cell death period (S. Montaldo and N. G. Forger, unpublished observations). The SNB of adult females may therefore provide an unusually stringent test of the rescue ability of Bcl-2, because motoneurons must be maintained indefinitely, despite the loss of major target sites.

Bcl-2 overexpression increased overall cell density in AVPV, but the number of dopaminergic neurons, as measured by $\mathrm{TH}$ immunoreactivity, was not affected by transgene expression. There are several possible explanations for this negative finding. First, it is possible that the sex difference in $\mathrm{TH}$ cell number arises not as the result of differential cell death of presumptive dompaminergic neurons but by some other mechanism, such as the hormonal specification of neuronal phenotype. Alternatively, the sex difference in TH-ir cell number in AVPV may indeed be caused by hormonally regulated cell death, but by a Bcl-2 independent pathway. For example, other Bcl-2 family members, such as Bcl-xL and Bax, and the cell surface Fas receptor are implicated in controlling the initiation of cell death cascades in developing neurons (Raoul et al., 1999; Martin, 2001).

Figure 3. Overall cell density and the number of tyrosine hydroxylase $(T H)$-immunoreactive neurons in AVPV. A, Overall cell density was higher in females than in males $(p<0.01)$. $\mathrm{Bcl}-2$ overexpression significantly increased AVPV cell density in males. $B$, Females had 3.3 times as many TH-immunoreactive neurons in AVPV as did males $(p<0.0005)$. $\mathrm{Bcl}-2$ overexpression had no effect on TH cell number in either sex. $n=$ numbers at base of bars.

The final common pathway for many types of cell death is the activation of cysteine proteases, known as "caspases," which degrade cellular proteins (for review, see Hengartner, 2000). Preliminary findings of Waters and Simerly (2002) indicate that estradiol markedly decreases TH cell number in organotypic slice cultures of newborn rat AVPV, and this decrease can be prevented by concomitant treatment with a caspase inhibitor. This suggests that cell death contributes, at least in part, to the hormonally controlled sex difference in TH cell number in AVPV and, taken together with the current findings, underscores the possibility that the molecular control of cell death varies not only from region to region, but also among subtypes of cells within a single neural region. The AVPV exhibits considerable cell type heterogeneity, and in addition to the sex difference in $\mathrm{TH}$ neurons, female rats have more neurons that express dynorphin, calcitonin gene-related peptide, neurotensin, and estrogen receptors (Alexander et al., 1991; Simerly, 1991; Bloch et al., 1992; Herbison and Dye, 1993). Although sexual differentiation of these cell types in the AVPV of mice has not yet been examined, overexpression of Bcl-2 may have reduced the sex difference in 
overall cell number in AVPV by reducing hormone-dependent cell death in any of these subpopulations of neurons.

Bcl-2 overexpression markedly increased the number of RDLN motoneurons categorized as small. Similarly, many of the facial motoneurons rescued in mice with a targeted deletion of the pro-death gene, Bax, are shrunken in size (Deckwerth et al., 1996). If Bcl-2 overexpression increases motoneuron survival without affecting size of the target muscles, then an increased number of motoneurons may be competing for a constant supply of target-derived trophic factors in the overexpressors. We did not examine RDLN target muscles, which are located in the foot. However, striated muscles are not likely to have been directly affected by Bcl-2 expression in the current study because the $\mathrm{Bcl}-2$ transgene was linked to a neuron-specific promoter. Moreover, as mentioned above, size of SNB target muscles was not affected by transgene expression. Thus, because target-derived trophic factors influence motoneuron size in adulthood (Elliott and Snider, 1996), there may be a subset of motoneurons in $\mathrm{Bcl}$-2-overexpressing mice that do not receive enough trophic support to promote a normal cell size yet are prevented from dying by excess Bcl-2. It is not known whether these cells are functional or, more generally, how neural circuits and the functions that they control may be altered in the brains and spinal cords of the cell death mutants.

Gonadal steroid hormones regulate cell death in the developing SNB and AVPV. Specifically, androgenic metabolites of testosterone reduce cell death in the SNB (Breedlove and Arnold, 1983), whereas estrogenic metabolites increase cell death in AVPV (Arai et al., 1996). It is possible that by increasing $\mathrm{Bcl}-2$ protein expression, some neurons would be maintained that ordinarily die in the SNB and AVPV, even if testosterone does not normally affect the expression or activity of Bcl-2. Alternatively, the present results suggest the possibility that the hormonal regulation of Bcl-2 family proteins may be an important mechanism whereby gonadal steroids sculpt sex differences in neuronal number. Numerous previous studies demonstrated that Bcl-2 mRNA and protein expression are controlled by gonadal steroid hormones in peripheral tissues and in cancer cell lines (Wang and Phang, 1995; Kandouz et al., 1996; Huang et al., 1997, 1999). Within the CNS, estradiol upregulates Bcl-2 in several brain regions of adults (GarciaSegura et al., 1998; Dubal et al., 1999; Green and Simpkins, 2000; Alkayed et al., 2001), and testosterone increases Bcl-2 immunoreactivity in the SNB of adult male rats (Zup and Forger, 2002). The hormonal control of Bcl-2 expression during neural development has been less well studied, although preliminary findings from our laboratory indicate that testosterone enhances Bcl-2 protein expression in SNB motoneurons of female rats during late embryonic life (Zup, 2002). In addition, an NMDA receptor antagonist that lowers testosterone levels of newborn male rats concomitantly decreases Bcl-2 expression and increases cell death in the preoptic area of the hypothalamus (Hsu et al., 2000). Although in most instances androgens or estrogens increase $\mathrm{Bcl}-2$ expression and promote cell survival, in other cases these hormones decrease Bcl-2 and cell viability (Lapointe et al., 1999). Thus, the same hormonal stimulus can drive Bcl-2-dependent cell death in opposite directions in a cell-type specific manner. Variables such as the steroid receptor subtypes and cofactors expressed by a given cell may determine the response to a given hormone and may explain how testosterone and its hormonal metabolites normally decrease cell death in some neural regions, whereas they increase cell death in others (cf. Nilsen et al., 2000).

\section{References}

Alexander MJ, Kirly ZJ, Leeman SE (1991) Sexually dimorphic distribution of neurotensin/neuromedin $\mathrm{N}$ mRNA in the rat preoptic area. J Comp Neurol 311:84-96.

Alkayed NJ, Goto S, Sugo N, Joh HD, Klaus J, Crain BJ, Bernard O, Traystman RJ, Hurn PD (2001) Estrogen and Bcl-2: gene induction and effect of transgene in experimental stroke. J Neurosci 21:7543-7550.

Allsopp TE, Wyatt S, Paterson HF, Davies AM (1993) The proto-oncogene bcl-2 can selectively rescue neurotrophic factor-dependent neurons from apoptosis. Cell 73:295-307.

Arai Y, Sekine Y, Murakami S (1996) Estrogen and apoptosis in the developing sexually dimorphic preoptic area in female rats. Neurosci Res 25:403-407.

Bleier R, Byne W, Siggelkow I (1982) Cytoarchitectonic sexual dimorphisms of the medial preoptic and anterior hypothalamic areas in guinea pig, rat, hamster, and mouse. J Comp Neurol 212:118-130.

Bloch GJ, Kurth SM, Akesson TR, Micevych PE (1992) Estrogenconcentrating cells within cell groups of the medial preoptic area: sex differences and co-localization with galanin-immunoreactive cells. Brain Res 595:301-308.

Bonfanti L, Strettoi E, Chierzi S, Cenni MC, Liu XH, Martinou J-C, Maffei L, RabacchiSA (1996) Protection of retinal ganglion cells from natural and axotomy-induced cell death in neonatal transgenic mice overexpressing bcl-2. J Neurosci 16:4186-4194.

Breedlove SM, Arnold AP (1980) Hormone accumulation in a sexually dimorphic motor nucleus of the rat spinal cord. Science 210:564-566.

Breedlove SM, Arnold AP (1983) Hormonal control of a developing neuromuscular system. I. Complete demasculinization of the male rat spinal nucleus of the bulbocavernosus using the anti-androgen flutamide. J Neurosci 3:417-423.

Cihak R, Gutmann E, Hanzlikova V (1970) Involution and hormoneinduced persistence of the M. Sphincter (levator) ani in female rats. J Anat 106:93-110.

Coulpier M, Junier MP, Peschanski M, Dreyfus PS (1996) Bcl-2 sensitivity differentiates two pathways for motoneuronal death in wobbler mutant mouse. J Neurosci 16:5897-5904.

Deckwerth TL, Elliot JL, Knudson CM, Johnson EMJ, Snider WD, Korsmeyer SJ (1996) BAX is required for neuronal death after trophic factor deprivation and during development. Neuron 17:401-411.

Dubal DB, Shughrue PJ, Wilson ME, Merchenthaler I, Wise PM (1999) Estradiol modulates bcl-2 in cerebral ischemia: a potential role for estrogen receptors. J Neurosci 19:6385-6393.

Dubois-Dauphin M, Frankowski H, Tsujimoto Y, Huarte J, Martinou JC (1994) Neonatal motoneurons overexpressing the bcl-2 protooncogene in transgenic mice are protected from axotomy-induced cell death. Proc Natl Acad Sci USA 91:3309-3313.

Elliott JL, Snider WD (1996) Motor neuron growth factors. Neurol 47[Suppl 2]:S47-S53.

Farlie PG, Dringen R, Rees SM, Kannourakis G, Bernard O (1995) bcl-2 transgene expression can protect neurons against developmental and induced cell death. Proc Natl Acad Sci USA 92:4397-4401.

Forger NG (2001) The development of sex differences in the nervous system. In: Developmental psychobiology, the handbook of behavioral neurobiology, Vol 13 (Blass E, ed), pp 153-208. New York: Plenum.

Forger NG, Hodges LL, Roberts SL, Breedlove SM (1992) Regulation of motoneuron death in the spinal nucleus of the bulbocavernosus. J Neurobiol 23:1192-1203.

Forger NG, Howell ML, Bengston L, MacKenzie L, DeChiara TM, Yancopoulos GD (1997) Sexual dimorphism in the spinal cord is absent in mice lacking the ciliary neurotrophic factor receptor. J Neurosci 17:9605-9612.

Garcia-Segura LM, Cardona-Gomez P, Naftolin F, Chowen JA (1998) Estradiol upregulates Bcl-2 expression in adult brain neurons. NeuroReport 9:593-597.

Green PS, Simpkins JW (2000) Neuroprotective effects of estrogens: potential mechanisms of action. Int J Dev Neurosci 18:347-358.

Hengartner MO (2000) The biochemistry of apoptosis. Nature 407: $770-776$.

Herbison AE, Dye S (1993) Perinatal and adult factors responsible for the sexually dimorphic calcitonin gene-related peptide-containing cell population in the rat preoptic area. Neuroscience 54:991-999. 
Hollyday M, Hamburger V (1976) Reduction of the naturally occurring motor neuron loss by enlargement of the periphery. J Comp Neurol 170:311-320.

Hsu C, Hsieh Y-L, Yang R-C, Hsu H-K (2000) Blockage of N-methyl-Daspartate receptors decreases testosterone levels and enhances postnatal neuronal apoptosis in the preoptic area of male rats. Neuroendocrinology 71:301-307.

Huang Y, Ray S, Reed JC, Ibrado AM, Tang C, Nawabi A, Bhalla K (1997) Estrogen increases intracellular p26Bcl-2 to p21Bax ratios and inhibits taxol-induced apoptosis of human breast cancer MCF-7 cells. Breast Cancer Res Treat 42:73-81.

Jordan CL, Breedlove SM, Arnold AP (1982) Sexual dimorphism and the influence of neonatal androgen in the dorsolateral motor nucleus of the rat lumbar spinal cord. Brain Res 249:309-314.

Kandouz M, Siromachkova M, Jacob D, Chretien Marquet B, Therwath A, Gompel A (1996) Antagonism between estradiol and progestin on Bcl-2 expression in breast-cancer cells. Int J Cancer 68:120-125.

Kandouz M, Lombet A, Perrot JY, Jacob D, Carvajal S, Kazem A, Rostene W, Therwath A, Gompel A (1999) Proapoptotic effects of antiestrogens, progestins and androgen in breast cancer cells. J Steroid Biochem Mol Biol 69:463-471.

Konigsmark BW (1970) Methods for the counting of neurons. In: Contemporary research methods in neuroanatomy (Nauta WJH, Ebbeson SOE, eds), pp 315-340. New York: Springer.

Lapointe J, Fournier A, Richard V, Labrie C (1999) Androgens downregulate bcl-2 protooncogene expression in ZR-75-1 human breast cancer cells. Endocrinology 140:416-421.

Leslie M, Forger NG, Breedlove SM (1991) Sexual dimorphism and androgen effects on spinal motoneurons innervating the rat flexor digitorum brevis. Brain Res 561:269-273.

Marangos PJ, Schmechel DE, Parma AM, Goodwin FK (1980) Developmental profile of neuron-specific (NSE) and non-neuronal (NNE) enolase. Brain Res 190:185-193.

Martin LJ (2001) Neuronal cell death in nervous system development, disease, and injury. Int J Mol Med 7:455-478.

Martinou JC, Dubois-Dauphin M, Staple JK, Rodriguez I, Frankowski H, Missotten M, Albertini P, Talabot D, Catsicas S, Pietra C (1994) Overexpression of BCL-2 in transgenic mice protects neurons from naturally occurring cell death and experimental ischemia. Neuron 13:1017-1030.

Murakami S, Arai Y (1989) Neuronal death in the developing sexually dimorphic periventricular nucleus of the preoptic area in the female rat: effect of neonatal androgen treatment. Neurosci Lett 102:185-190.

Nilsen J, Mor G, Naftolin F (2000) Estrogen-regulated developmental neuronal apoptosis is determined by estrogen receptor subtype and the Fas/ Fas ligand system. J Neurobiol 43:64-78.

Nishizuka M, Sumida H, Kano Y, Arai Y (1993) Formation of neurons in the sexually dimorphic anteroventral periventricular nucleus of the preoptic area of the rat: effects of prenatal treatment with testosterone propionate. J Neuroendocrinol 5:569-573.

Nordeen EJ, Nordeen KW, Sengelaub DR, Arnold AP (1985) Androgens prevent normally occurring cell death in a sexually dimorphic spinal nucleus. Science 229:671-673.
Oppenheim RW (1991) Cell death during development of the nervous system. Annu Rev Neurosci 14:453-501.

Park JJ, Howell M, Winseck A, Forger NG (1999) Effects of testosterone on the development of a sexually dimorphic neuromuscular system in ciliary neurotrophic factor receptor knockout mice. J Neurobiol 41:317-325.

Park JJ, Zup SL, Verhovshek T, Sengelaub DR, Forger NG (2002) Castration reduces motoneuron soma size but not dendritic length in the spinal nucleus of the bulbocavernosus of wild-type and BCL-2 overexpressing mice. J Neurobiol 53:403-412.

Raoul C, Henderson CE, Pettmann B (1999) Programmed cell death of embryonic motoneurons triggered through the Fas death receptor. J Cell Biol 147:1049-1062.

Schroder HD (1980) Organization of the motoneurons innervating the pelvic muscles of the male rats. J Comp Neurol 192:567-587.

Simerly RB (1991) Prodynorphin and proenkephalin gene expression in the anteroventral periventricular nucleus of the rat: sexual differentiation and hormonal regulation. Mol Cell Neurosci 2:473-484.

Simerly RB (1998) Organization and regulation of sexually dimorphic neuroendocrine pathways. Behav Brain Res 92:195-203.

Simerly RB, Swanson LW, Handa RJ, Gorski RA (1985) Influence of perinatal androgen on the sexually dimorphic distribution of tyrosine hydroxylase-immunoreactive cells and fibers in the anteroventral periventricular nucleus of the rat. Neuroendocrinology 40:501-510.

Simerly RB, Zee MC, Pendleton JW, Lubahn DB, Korach KS (1997) Estrogen receptor-dependent sexual differentiation of dopaminergic neurons in the preoptic region of the mouse. Proc Natl Acad Sci USA 94: 14077-14082.

Sumida H, Nishizuka M, Kano Y, Arai Y (1993) Sex differences in the anteroventral periventricular nucleus of the preoptic area and in the related effects of androgen in prenatal rats. Neurosci Lett 151:41-44.

Tobet SA, Hanna IK (1997) Ontogeny of sex differences in the mammalian hypothalamus and preoptic area. Cell Mol Neurobiol 17:565-601.

Tobin C, Joubert Y (1991) Testosterone-induced development of the rat levator ani muscle. Dev Biol 146:131-138.

Wagner CK, Clemens LG (1989) Perinatal modification of a sexually dimorphic motor nucleus in the spinal cord of the B6D2F1 house mouse Physiol Behav 45:831-835.

Wang TT, Phang JM (1995) Effects of estrogen on apoptotic pathways in human breast cancer cell line MCF-7. Cancer Res 55:2487-2489.

Waters EM, Simerly RB (2002) Estrogen-mediated programmed cell death during development of a sexually dimorphic hypothalamic nucleus. Soc Neurosci Abstr 28:33.5.

Wee B, Clemens LG (1987) Characteristics of the spinal nucleus of the bulbocavernosus are influenced by genotype in the house mouse. Brain Res 424:305-310.

Yang E, Korsmeyer SJ (1996) Molecular thanatopsis: a discourse on the BCL2 family and cell death. Blood 88:386-401.

Zup SL (2002) The role of Bcl-2 family members in sexual differentiation and adult neural plasticity. $\mathrm{PhD}$ thesis, University of Massachusetts.

Zup SL, Forger NG (2002) Testosterone regulates BCL-2 immunoreactivity in a sexually dimorphic motor pool of adult rats. Brain Res 950:312-316. 